\title{
HUMAN RESOURCES DEVELOPMENT FOR TOURISM SECTOR (PENGEMBANGAN MODEL PENINGKATAN KAPASITAS SUMBER DAYA MANUSIA PARIWISATA MICE KHUSUSNYA PENYELENGGARA INSENTIVE TRAVEL)
}

Oleh:

John Sihar Manurung

\begin{abstract}
Abstrak
Pengembangan sumber daya manusia sektor Pariwisata merupakan salah satu upaya Pemerintah dalam melakukan pembangunan berkesinambungan yang direncanakan melalui sektor Pariwisata yang dulunya dengan mengemas kebijakan Pariwisata untuk mendatangkan kuantitas sebanyak-banyaknya wisatawan mancanegara (Wisman), akan tetapi pada masa ini bahwa kebijakan Pariwisata MICE lebih menekankan pada kualitas wisatawan yang dapat menambah pundi devisa melalui Pariwisata Mancanegara dan Domestik yang akan melakukan kegiatan Rapat (Meeting), Perjalanan Dinas (Insentive), Konfrensi (Confrence), Pameran (Exibition) di Indonesia. Untuk mendukung Kebijakan Pemerintah dalam arah haluan Pariwisata Mice maka diharapkan melalui sektor swasta dan masyarakat dapat melakukan pengembangan kapasitas sumber daya manusia dengan model atau pola yang dapat dimanfaatkan oleh para penyelenggara Pariwisata di Indonesia. Pengelolaan Sumber daya manusia Pariwisata MICE telah dituangkan dalam UU No 10 tahun 2004, bab 3 pasal 5 mengenai sumber daya manusia pariwisata dalam pembangunan kepariwisataan, terdiri dari sumber daya alam ciptaan Tuhan Yang Maha Esa berupa letak geografi, kepulauan, laut, flora dan fauna, sungai, danau, hutan bentang alam, iklim; sumber daya hasil karya manusia berupa hasil-hasil rekayasa sumber daya alam, perkotaan, kebudayaan, nilai-nilai sosial, warisan sejarah, dan teknologi; dan sumber daya manusia berupa kesiapan, kompetensi, komitmen dan peran serta masyarakat.

Kajian ini bertujuan untuk menemukan Pengembangan Model Kapasitas Sumber daya manusia yang sesuai dengan keinginan sektor swasta dan masyarakat khususnya penyelenggara Pariwisata MICE khususnya di Sumatera Utara dan secara umum sebagai bahan masukan dalam mewujudkan Indosesia sebagai salah satu Negara Destinasi Insentive. Adapun tujuan khusus, antara lain: 1).Untuk mengevaluasi kapasitas sumber daya manusia penyelenggara insentive travel di Sumatera Utara. 2).Sebagai model pengembangan kapasitas sumber daya manusia penyelenggara insentive travel di Sumatera Utara. 3).Untuk mendukung kebijakan Pariwisata dalam peningkatan kapasitas sumber daya manusia penyelenggara Insentive travel pasca penetapan Sumatera Utara sebagai salah satu kota destinasi Insentive travel. Sedangkan manfaat secara tioritis dapat memberikan bukti empiris tentang program Insentive Travel David Kelly (2012), Severt S. \& Breiter D.(2010), Motivasi Kerja Mc Clelland (1987), dan Kinerja Sumber daya manusia Bernardin dan Russell (1993), dikaitkan dengan motivasi kerja berprestasi dan kinerja sumber daya manusia. Sedangkan manfaat praktis, antara lain: 1). Memberikan sumbangan pemikiran dalam pengambilan kebijakan
\end{abstract}


kepada pimpinan perusahaan tentang pemberian program insentive yang tepat dalam meningkatkan motivasi kerja dan kinerja sumber daya manusia berprestasi. 2). Memberikan sumbangan pemikiran yang konstruktif tentang implementasi program insentive travel kepada pihak terkait diantara Pemerintah dan Swasta untuk menunjang pengembangan Pariwisata MICE dan Sumatera Utara sebagai destinasi insentif tahun 2015.

Kajian ini akan menemukan model pengembangan kapasitas Sumber daya manusia penyelenggara Pariwisata MICE khususnya di Sumatera Utara, dimana kapasitas Sumber daya manusia ditemukan berada pada haluan yang benar dengan berbagai kemajuan, meskipun masih ditemukan beberapa hal kelemahan (weakness) dan permasalahan serta sasaran yang belum terwujud sesuai harapan dan standart keinginan wisatawan yang jika tidak teratasi akan menjadi ancaman bagi pertumbuhan pariwisata (threat). Sementara berdasarkan hasil analisis keadaan kapasitas sumber daya manusia ditemukan adanya beberapa kekuatan (strength) dan peluang (opportunity). Tantangan pariwisata dari sisi eksternal seperti daya saing pariwisata Indonesia di tingkat Internasional menjadi hal prioritas sebagai salah satu factor penting dalam penentuan destinasi wisata, sementara kelemahan sisi internal yaitu rendahnya Sumber daya manusia, budaya dan kearifan lokal yang kurang, dan kelemahan konnektivitas penerbangan serta terbatasnya infrastruktur terutama di lokasi wisata, sampai pada kurangnya venue pendukung pariwisata MICE.

Rekomendasi pada Pengembangan Kapasitas Sumber daya manusia agar mampu memberikan pelayanan yang berkualitas, arah kebijakan Pemerintah yang berpihak pada pariwisata MICE, evaluasi konektivitas akses transportasi ke lokasi destinasi pariwisata, penyediaan kebutuhan Venue MICE yang memadai, Tempattempat yang strategis, harga dan kualitas produk pariwisata yang cukup bersaing, suasana dan pelayanan wisata yang nyaman,Venue Alam wisata yang baik dan menarik yang selalu terjaga dan tertata rapi serta Keramahan dan sopan santun dalam budaya Masyarakat lokasi wisata yang harus ditingkatkan menjadi sangat penting.

Kata Kunci: Pariwisata MICE, Kapasitas Sdm, kebijakan Pemerintah.

\section{Latar Belakang}

Era globalisasi saat ini akan semakin membuka mata untuk melihat masa depan yang penuh dengan tantangan ekonomi dan persaingan global. Salah satu yang terpenting adalah daya saing ekonomi yang tinggi, yang tentu saja harus didukung oleh sumber daya manusia yang berkualitas tinggi. Globalisasi merupakan cara pandang atau pertukaran pemikiran manusia, komunikasi yang serba cepat dan canggih dalam semua aspek kehidupan manusia didunia. Kemajuan infrastruktur transportasi dan telekomunikasi, termasuk kemunculan telegraf dan internet, merupakan faktor utama dalam globalisasi yang semakin mendorong saling ketergantungan (interdependensi) aktivitas ekonomi dan budaya Stever dalam Wikipedia (2014).

Asean Economic Community (AEC) tahun 2015 yang akan datang sudah di ambang pintu dan tentu saja harus mempersiapkan diri terutama para pelaku 
bisnis dan industri di Indonesia dan di daerah seperti halnya di Sumatera Utara. Menurut Fathur Anas (2014) mengatakan banyak yang menilai bahwa Indonesia belum siap dalam menghadapi Asean Economic Community (AEC), sebab daya saing sumber daya manusia maupun produk yang masih kalah bersaing dengan produk impor lainnya. Pada hal bila dicermati bersama, dibandingkan dengan sembilan negara anggota Asean lain, Indonesia memiliki sejumlah keunggulan yang dapat difungsikan menjadi modal berharga dalam menghadapi AEC. Negara dengan jumlah penduduk terbesar di kawasan Asia Tenggara, saat ini mencapai 251.160.124 jiwa estmasi Juli 2013 (Dickson, 2013).

Jumlah Penduduk Asean (Estimasi Juli, 2013)

\begin{tabular}{|l|l|r|}
\hline No & Negara & Jumlah Penduduk (Jiwa) \\
\hline 1 & Indonesia & 251.160 .124 \\
\hline 2 & Malaysia & 29.628 .392 \\
\hline 3 & Thailand & 67.448 .120 \\
\hline 4 & Filiphina & 105.720 .644 \\
\hline 5 & Singapura & 5.460 .302 \\
\hline 6 & Brunai Darussalam & 415.717 \\
\hline 7 & Vietnam & 92.477 .857 \\
\hline 8 & Laos & 6.695 .166 \\
\hline 9 & Myanmar & 55.167 .330 \\
\hline 10 & Kamboja & 15.205 .539 \\
\hline & Jumlah & 629.379 .191 \\
\hline
\end{tabular}

Sumber: Dickson, Ilmu Pengetahuan Umum, Teknologi dan Daftar Top 10 di Dunia, 26 Desember 2013.

Fakta jumlah penduduk yang hampir 40\% atau sekitar 39,91\% menggambarkan bahwa Indonesia memiliki ketersediaan sumber daya manusia sangat mencukupi untuk bersaing di ekonomi regional, berpotensi memberikan pengaruh besar bagi terwujudnya $A E C$ dengan cara melakukan penataan kembali terhadap pengembangan sumber daya manusia kearah kepemilikan kapasitas dan kompetensi yang lebih baik dengan sertifikasi berkualitas agar dapat meningkatkan produktivitas kerja dengan harapan untuk mendapat reward yang lebih baik.

Berbagai upaya yang dilakukan oleh Pemerintah Indonesia dalam memecahkan beberapa persoalan sumber daya manusia, yang bertujuan menciptakan keterkaitan dunia pendidikan dan kebutuhan industri diantaranya melalui program Link and Macht, program kurikulum nasional berbasis kompetensi oleh Departemen Pendidikan Nasional, program sertifikasi oleh Badan Nasional Sertifikasi Pekerja (BNSP), Standarisasi Kompetensi Kerja Nasional Indonesia (SKKNI) oleh Kementerian Industri. Hal ini dilakukan untuk menghasilkan sumber daya manusia yang unggul dan memenuhi syarat terhadap tuntutan demand industry sebagai user tenaga kerja.

Pengembangan kapasitas dalam kinerja sumber daya manusia berprestasi dalam perusahaan akan menjadi perihal penting disebabkan ruang lingkup organisasi, maka kinerja merupakan kunci efektivitas organisasi yang didukung oleh sumber daya manusia yang berkualitas. Menurut Fendy Suhariadi (2013), 
kinerja merupakan suatu fungsi motivasi dan kemampuan. Untuk menyelesaikan tugas atau pekerjaan, seseorang harus memiliki derajat kesediaan dan tingkat kemampuan tertentu. Kesediaan dan keterampilan seseorang tidak cukup efektif untuk mengerjakan sesuatu tanpa pemahaman yang jelas tentang apa yang akan dikerjakan dan bagaimana mengerjakannya. Dalam konteks hasil oleh Bernardin (2003) mengatakan kinerja merupakan catatan hasil yang diproduksi atas fungsi pekerjaan tertentu atau akibat aktivitas pada periode waktu tertentu. McCelland (1987), dalam tiori motivasi berprestasi menyatakan seseorang dianggap memiliki motivasi untuk berprestasi jika ia mempunyai keinginan untuk melakukan sesuatu karya berprestasi lebih baik dari prestasi karya orang lain.

David Kelly (2012) menguatkan Severt K \& Breiter D (2010), merekomendasikan elemen Insentive Travel untuk usaha menjadi sukses sebagai pengembangan kapasitas penyelenggara pariwisata, antara lain:

1. Kriteria penerima penghargaaan harus jelas mengarah pada tujuan bisnis,

2. Komunikasi program dan progress peserta tentang tujuan kedepan harus jelas dan konsisten,

3. Design program perjalanan meliputi destinasi yang dinginkan dan terjangkau, sesi enteraktif dan hiburan yang menarik,

4. Eksekutif dan manager kunci bertindak sebagai pemandu dalam penguatan komitmen perusahaan pada program penghargaan dan rekognisi,

5. Perusahaan membuat laporan rinci perihal produktivitas penerima dan kontribusinya pada kinerja keuangan perusahaan.

Selain itu, David Kelly menyimpulkan saran untuk memaksimalkan manfaat dari program perjalanan insentif harus disertakan, antara lain:

6. Rekognisi penerima,

7. Kesempatan networking bagi top performer untuk membangun hubungan dengan top performer lainnya dan manajemen kunci,

8. Kolaborasi diantara top performer dan manajemen tentang ide dan praktek kerja terbaik, dan

9. Motivasi penerima untuk melanjutkan pencapaian kinerja tinggi.

Penelitian empirik oleh Incentive Research Foundation Landmark (2008), studi yang mengkaji tentang Pasar Incentive travel, Motivasi rapat dan Acara spesial, menunjukkan besaran budget pengeluaran perusahaan pada tahun 2006 sebesar \$77.1 Billiun, dengan rincian pengeluaran, antara lain: Insentif Perjalanan: pengalaman perjalanan untuk memotivasi dan menghargai kinerja yang unggul (tidak ketat bisnis) sebesar \$13.4 atau 17\%. Pertemuan Motivasi: mencakup unsur motivasi yang dirasakan untuk rekreasi, motivasi pidato, penghargaan, dan kegiatan membangun tim kerja sebesar \$25.9 atau 34\%. Dan Acara khusus (spesial): kegiatan yang meliputi pertemuan penjualan, konvensi, pertemuan bisnis dan pertemuan social (perjamuan, teater, atau tempat olah raga) \$37.8 atau 49\%. 
Tabel.1.

Perusahaan Yang Menerapkan Program Insentive Travel Sebagai Salah Satu Cara Dalam Pengembangan SDM Pada Perusahaan Swasta Di Sumatera Utara

\begin{tabular}{|l|l|l|l|l|}
\hline \multirow{2}{*}{ No } & \multirow{2}{*}{$\begin{array}{l}\text { Jenis } \\
\text { Perusahaan }\end{array}$} & \multicolumn{2}{|l|}{ Bentuk Insentive } \\
\cline { 3 - 5 } & Insentive Travel & $\begin{array}{l}\text { Motivasional } \\
\text { Meeting }\end{array}$ & $\begin{array}{l}\text { Spesial } \\
\text { Event }\end{array}$ \\
\hline 1 & Asuransi & Ya & Ya & Ya/Jarang \\
\hline 2 & Otomotif & Ya & Ya & Ya/Jarang \\
\hline 3 & Investasi & Ya & Rapim & Tidak pernah \\
\hline 4 & $\begin{array}{l}\text { Institusi } \\
\text { Pendidikan }\end{array}$ & $\begin{array}{l}\text { Ya/Tidak } \\
\text { (Bersama) }\end{array}$ & $\begin{array}{l}\text { Seminar,pelatihan, } \\
\text { study banding }\end{array}$ & Tidak pernah \\
\hline 5 & Agri Bisnis & Tidak pernah & Rapim & Tidak pernah \\
\hline 6 & Travel Agent & Ya/Pimpinan & Rapim & Tidak pernah \\
\hline 7 & Real Estate & Ya & Rapim & Tidak pernah \\
\hline
\end{tabular}

Sumber: Pengolahan Data Wawancara Lapangan

Pengamatan dan wawancara yang dilakukan pada pimpinan dan karyawan beberapa perusahaan swasta di Sumatera Utara dapat disimpulkan bahwa belum berkembangnya budaya reward insentive travel, motivasi rapat dan spesial event, seperti dalam table diatas. Insentive travel mayoritas hanya diberikan perusahaan yang bergerak dalam bidang penjualan produk saja yaitu perusahaan asuransi, otomotif, investasi, real estate sedangkan institusi pendidikan dilakukan hanya sebagai program bersama untuk menjalin kebersamaan, agribisnis tidak pernah melakukan program insentive travel sedangkan perusahaan travel agent pernah melakukan insentive travel oleh pimpinan saja karena ada penghargaan dari mitra kerja seperti mitra penerbangan. Insentive motivasional rapat diberikan sebagai insentive oleh perusahaan asuransi dan otomotif, perusahaan lainnya memilih peserta melakukan rapat pimpinan hanya karena kapasitasnya sebagai pimpinan dan bukan karena kriteria kinerja yang baik atau bukan berdasarkan pencapaian prestasi kerja, sedangkan instansi pendidikan memilih peserta seminar, training, studi banding, rapat kurikulum dilakukan bukan juga pesertanya karena pencapaian kinerja yang baik akan tetapi lebih pada keinginan staf, pengampu mata kuliah dan kapasitas jabatan. Sedangkan Insentive spesial event, pesertanya tidak pernah dan sangat jarang dilakukan dari dan oleh karyawan perusahaan sebagai bagian dari pencapaian kinerja, akan tetapi dilakukan perusahaan dengan bekerjasama dengan pihak ketiga untuk meningkatkan soliditas atau brand/merk perusahaan sebagai bagian dari program peduli.

Severt and Breiter (2010) menyatakan bahwa program insentive travel dirancang untuk memberikan arah yang jelas bagi perusahaan untuk memberikan penghargaan dalam bentuk perjalanan kepada seluruh karyawan yang memiliki kapasitas dan kemampuan kerja tinggi, pemenang hanya 10\% dari karyawan. Proses seleksi pada karyawan pemenang program insentive meliputi seluruh 
karyawan perusahaan yang dilakukan melalui seleksi pencapaian produktivitas dan kinerja masing-masing karyawan dan program ini tidak dibatasi hanya pada karyawan berproduktivitas yang berhubungan langsung dengan keuntungan operasi bersih dan/atau keuntungan kotor namun dengan kualifikasi terdiri dari: kualifikasi produksi maupun kualifikasi pelayanan.

Dalam mengembangkan industri Pariwisata di Indonesia, penting rasanya digalakkan pengembangan promosi dan pemasaran terpadu yang berkelanjutan, sehingga diharapkan hal tersebut bakal berdampak langsung pada multiplayer effect, baik dari sisi ekonomi, perdagangan, industri, dan pencitraan di kancah nasional maupun internasional. Sebagai industri yang memiliki karakter multiplayer effect, MICE tentunya dapat meningkatkan taraf ekonomi masyarakat sekitar, karena dalam suatu event, seluruh stakeholder akan ikut terlibat. Selain itu, angka pengangguran juga akan bisa ditekan melalui industri Mice Kementerian Perdagangan RI (2011). Menurut Kesrul (2004:3), Mice sebagai suatu kegiatan kepariwisataan yang aktifitasnya merupakan perpaduan antara leisure dan business, biasanya melibatkan sekelompok orang secara bersama- sama, rangkaian kegiatannya dalam bentuk meetings, incentive travels, conventions, congresses, conference and exhibition.

Sumatera Utara sebagai salah satu daerah di Indonesia yang dicanangkan Kemenparakraf sebagai destinasi insentive tahun 2015 yang akan datang, FGD Penyusunan Strategi Pengembangan Mice (2014). Meski jumlah kunjungan wisatawan mancanegara (wisman) Sumut, terus naik atau sudah mencapai 241.830 orang pada 2012 atau naik 8,38 persen dari 2011 yang masih sebanyak

223.126 orang, tetapi jumlah itu belum pulih dibandingkan di era tahun 1990-an yang berjumlah 400 ribu orang, Solahuddin (2014). Atas dasar data kunjungan wisata diatas disimpulkan bahwa sangat perlu kiranya dilakukan beberapa usaha yang mendukung pada perkembangan pariwisata dan tentu saja perlu dalama pengembangan kapasitas sumber daya manusia pariwisata MICEdiSumateraUtara.

Hasil wawancara dengan Departemen Pariwisata Marketing MICE di Medan mengenai potensi wisata di Sumatera Utara, tidak salah lagi merasa bangga melihat beberapa daerah wisata menjadi primadona, seperti Danau Toba, Berastagi, Bukit Lawang, Tangkahan dan daerah tujuan wisata lainnya memiliki potensi diantaranya majunya peluang bisnis, heritage, culiner, culture, venue alam yang indah. Namun juga memiliki beberapa kelemahan yang harus ditata ulang, seperti: konektifitas infrastruktur daerah yaitu jalan raya dan transfortasi yang bagus, teknologi komunikasi yang lengkap seperti fasilitas internet $\mathrm{WiFi}$, banking sistem dan lainnya sampai kepada attitude atau feel to be conform yaitu sikap masyarakat yang tidak masa bodoh (uncare), sikap tidak menolong (unhelpful) yang harus menjadi tugas bersama untuk melakukan edukasi terhadap masyarakat agar benar-benar sadar wisata (darwis) dan dengan demikian dapat memperpanjang lama berwisata (longstay) dan juga adanya paket-paket wisata khusus, dengan rata-rata 4 kunjungan dengan budget rata-rata \$500.- perhari.

Data perkembangan wisatawan mancanegara dan domestik ke Sumatera Utara menunjukkan peningkatan dari tahun ke tahun dimana pada tahun 2010 sebanyak 191.466, naik menjadi tahun 2011 sebanyak 223.126, naik di tahun 
2012 sebanyak 241.833, dan naik menjadi 259.299 pada tahun 2013 dan tahun 2014 dibanding 2013 per bulan januari 22.594 naik sebesar 30,78\%, bulan pebruari 22.058 naik sebesar $15,28 \%$, bulan maret 21.374 secara persentase turun menjadi $1,67 \%$.

Tabel 3.

DATA WISATAWAN MANCANEGARA KE SUMUT TAHUN 2010 - 2014

\begin{tabular}{|l|l|c|c|c|c|c|l|}
\hline NO & BULAN & \multicolumn{3}{|l|}{ TAHUN } & \multicolumn{2}{l|}{} & $\begin{array}{l}\text { PERTUM } \\
\text { BUHAN (\%) } \\
\text { 2013 KE 2014 } \\
\text { (BULAN) }\end{array}$ \\
\cline { 3 - 8 } & & 2010 & 2011 & 2012 & 2013 & 2014 & \\
\hline 1 & JANUARI & 14067 & 15757 & 18139 & 17277 & 22594 & 30,78 \\
\hline 2 & FEBRUARI & 15765 & 17034 & 17580 & 19135 & 22058 & 15,28 \\
\hline 3 & MARET & 17038 & 17138 & 22123 & 21738 & 21374 & $-1,67$ \\
\hline 4 & APRIL & 15091 & 17192 & 19386 & 17503 & 19072 & \\
\hline 5 & MEI & 15959 & 19133 & 21137 & 23711 & & \\
\hline 6 & JUNI & 17303 & 18888 & 19128 & 23490 & & \\
\hline 7 & JULI & 16207 & 19911 & 18273 & 18188 & & \\
\hline 8 & AGUSTUS & 13585 & 16289 & 18511 & 18960 & & \\
\hline 9 & SEPTEMBER & 14782 & 16522 & 19092 & 20949 & & \\
\hline 10 & OKTOBER & 15848 & 17289 & 18720 & 20158 & & \\
\hline 11 & NOVEMBER & 16543 & 22846 & 24481 & 27310 & & \\
\hline 12 & DESEMBER & 19278 & 25127 & 25263 & 30880 & & \\
\hline & JUMLAH & 191466 & 223126 & 241833 & 259299 & 66026 & \\
\hline
\end{tabular}

Sumber: BPS Sumut/Dep. Pariwisata Bagian Marketing MICE Medan, per Mei 2014.

Kenaikan jumlah wisman pada tahun 2011 seiring dengan upaya sejumlah 33 Pemda/ko melakukan revitalisasi kawasan wisata, seperti Danau Toba, Berastagi, Bukit Lawang dan lainnya serta peningkatan kunjungan masyarakat lima negara, yaitu Taiwan, Korea Selatan, Singapura, Malaysia, dan Inggris, namun terjadi penurunan kunjungan wisman dari beberapa negara di Eropa. Data BPS menunjukkan turis asing yang datang melalui Bandara Polonia sebanyak

22.296 orang pada Desember 2011, sisanya melalui Pelabuhan Belawan sebanyak 1.703 orang, dan 1.748 orang melalui Pelabuhan Tanjung Balai. Ditambahkan juga bahwa wisman yang paling banyak datang ke Sumut pada Desember berasal dari Malaysia, Singapura, Taiwan, Belanda, dan Amerika. Namun kenaikan kunjungan Wisman diatas tidak serta merta dikategorikan sebagai kunjungan wisata insentive. Penyusunan strategi pengembangan Destinasi Mice yang berlangsung tanggal 5 Juni 2014 di Medan dalam upaya pemetaan Sumut sebagai Destinasi Insentive 2015 di Indonesia, dan juga terkait daya saing Indonesia pada tahun 2013 bahwa Indonesia belum termasuk dalam rangking 20 besar ICCA, namun pada tahun 2012 Indonesia masuk urutan 41, Asia Fasifik 292 Indonesia urutan 11, World City Ranking Jakarta pada urutan 176, Bali pada urutan 48 maka diharapkan dapat diperbaiki apalagi menjelang MEA tahun 2015 bahwa sumber daya manusia sudah pada taraf pemilikan sertifikasi. Selain Bali dan Jakarta bahwa Medan menjadi target utama wilayah Barat dalam pemetaan kota tujuan 
wisata Incentive maka ditetapkan 9 kriteria dan 67 indikator dengan pertimbangan bahwa Gap antara Evaluasi Diri dan Expert Judgement destinasi Mice dipulau Sumatera dengan skor paling rendah sebesar 0,62 diantara Batam, Bintan, Padang, dan Palembang FGD Pengembangan Mice (2014). Penelitian inidiperlukan dalam rangka pengembangan kapasitas Sdm Pariwisata MICE guna dapat memberikan pelayanan pada wisatawan diatas.

Mendengar masukan pada FGD Menparekraf yang diselenggarakan di Medan, dengan Instansi terkait dan sejumlah Pengusaha di Sumatera Utara, yang mencanangkan Medan sebagai prioritas di wilayah barat sebagai destinasi incentive tahun 2015, untuk menyiapkan sumber daya manusia terutama jika dikaitkan dengan bunyi UU No.10 Tahun 2004 bab 3 pasal 5 ayat c diatas, dapat diartikan bahwa sumber daya manusia harus disiapkan sebaik mungkin, kompetensi, sertifikasi, serta komitmen tinggi. Maka penelitian ini diharapkan memperoleh manfaat untuk membantu karyawan, eksekutip, para praktisi dan masyarakat dalam melakukan pengembangan kapasitas sumber daya manusia, menumbuhkan serta menggalakkan penguatan budaya reward insentive travel guna meningkatkan kunjungan wisata ke Sumatera Utara sebagai destinasi insentive di Indonesia.

\section{Rumusan Masalah}

Berdasarkan uraian pada latar belakang di atas maka terdapat beberapa permasalahan yang berhubungan dengan insentive travel, dan kinerja sumber daya manusia, dapat dirumuskan sebagai berikut:

1. Bagaimanakah kapasitas Sumber daya manusia perusahaan penyelenggara Insentive travel di Sumatera Utara?

2. Bagaimana model pengembangan kapasitas sumber daya manusia perusahaan penyelenggara Insentive travel di Sumatera Utara?

3. Bagaimana Kebijakan Pemerintah dibidang pariwisata dapat mendukung meningkatnya kapasitas sumber daya manusia penyelenggara Insentive travel di Sumatera Utara?

\section{Tujuan dan Manfaat Penelitian}

Berdasarkan rumusan permasalahan penelitian maka dapat dikemukakan tujuan penelitian adalah:

1. Untuk mengevaluasi kapasitas sumber daya manusia penyelenggara insentive travel di Sumatera Utara.

2. Sebagai model pengembangan kapasitas sumber daya manusia penyelenggara insentive travel di Sumatera Utara.

3. Untuk mendukung kebijakan Pariwisata dalam peningkatan kapasitas sumber daya manusia penyelenggara Insentive travel, pasca penetapan Sumatera Utara sebagai destinasi Insentive travel mulai tahun 2015.

Adapun manfaat tioritis, dapat memberikan bukti empiris tentang program insentive travel dari David Kelly (2012), Severt S. \& Breiter D.(2010), motivasi kerja Mc Clelland (1987), dan kinerja sumber daya manusia dari Bernardin dan Russell (1993). Sedangkan manfaat praktis dalam penelitian ini diharapkan, antara lain: 
1.Dapat memberikan sumbangan pemikiran dalam pengambilan kebijakan kepada pimpinan perusahaan tentang pemberian program insentive yang tepat dalam meningkatkan motivasi kerja dan kinerja sumber daya manusia berprestasi.

2.Dapat memberikan sumbangan pemikiran yang konstruktif tentang implementasi program insentive travel kepada pihak terkait diantara Pemerintah dan Swasta untuk menunjang pengembangan Pariwisata MICE dan Sumatera Utara sebagai destinasi insentif tahun 2015.

\section{TINJAUAN PUSTAKA}

\section{Kinerja Sebagai Gambaran Kapasitas Sumber Daya Manusia}

Kinerja sebagai perilaku dan gambaran kapasitas sumber daya manusia dikemukakan oleh Murphy dalam Sudarmanto (2009) mengatakan bahwa kinerja merupakan seperangkat perilaku yang relevan dengan tujuan organisasi atau unit organisasi tempat orang bekerja. Dalam konteks hasil oleh Bernardin (2003) mengatakan kinerja merupakan catatan hasil yang diproduksi atas fungsi pekerjaan tertentu atau akibat aktivitas pada periode waktu tertentu. Fendy Suhariadi (2013), Kinerja (performance) individu sangat penting artinya bagi organisasi. Kontribusikontribusi yang diberikan oleh pegawai untuk mencapai tujuan-tujuan organisasi yang merupakan hasil (output) sumber daya manusia disebut sebagai kinerja individu yang berarti seberapa efektif seorang pegawai menyelesaikan tanggung jawab kerjanya adalah sangat signifikan dengan upaya pencapaian tujuan organisasi. Pegawai yang memiliki kinerja yang tinggi berhasil menyelesaikan tanggung jawabnya dan membuat suatu kontribusi untuk target/sasaran organisasi (efisiensi dan peningkatan produktivitas).

Selanjutnya mengenai pengukuran kinerja dikemukakan Bernandin \& Russell yang dikutip oleh Faustino Cardoso Gomes (2000), dalam bukunya Human Resource Managemen, sebagai berikut:

1. Quantity of work : jumlah kerja yang dilakukan dalam suatu periode yang ditentukan.

2. Quality of work : kualitas kerja yang dicapai berdasarkan syarat-syarat kesesuaian dan kesiapanya.

3. Job Knowledge: luasnya pengetahuan mengenai pekerjaan dan keterampilannya.

4. Creativeness: keaslian gagasan-gagasan yang dimunculkan dan tindakan- tindakan untuk menyelesaikan persoalan-persoalan yang timbul.

5. Cooperation: kesediaan untuk bekerjasama dengan orang lain atau sesama anggota organisasi.

6. Dependability: kesadaran untuk dapat dipercaya dalam hal kehadiran dan penyelesaian kerja.

7. Initiative: semangat untuk melaksanakan tugas-tugas baru dan dalam memperbesar tanggungjawabnya.

8. Personal Qualities: menyangkut kepribadian, kepemimpinan, keramah tamahan dan integritas pribadi. Faustino cardoso gomes (2000). 
Sedangkan penurunan kinerja perusahaan merupakan penurunan kapasitas sumber daya manusia, dimana menurut Isywara Mahendratto (2007) bahwa penurunan kinerja, antara lain:

1. Beban kerja berlebihan: Terlalu banyaknya pekerjaan, sedikitnya waktu yang tersedia dan tidak adanya dukungan sistem menghabiskan cadangan sumber daya dan berdampak pada menurunnya kualitas kerja. Misal: rasio perawat dengan jumlah pasien yang tidak seimbang, banyaknya jumlah transaksi yang harus dilakukan petugas bank, manajer yang terlalu banyak melakukan tugas administratif dan sebagainya.

2 Kurangnya wewenang : Besarnya tanggung jawab yang harus dipikul namun tidak disertai wewenang dalam membuat keputusan. Misal: campur tangan atasan yang berlebihan sampai ke aspek tehnis, standar operating prosedur (SOP) yang terlalu kaku dan sebagainya.

3. Imbalan yang tidak memadai: Kecilnya upah dibandingkan dengan volume pekerjaan, tidak menariknya skema insentif dari target yang ingin dicapai, terjadinya perubahan kebijakan yang lebih buruk dari kebijakan sebelumnya. Misal: penundaan kenaikan upah, perubahan menjadi tenaga kontrak, pengurangan tunjangan kesejahteraan, ditiadakannya bonus dan sebagainya.

4. Skema insentive yang tidak menarik: tidak adanya variasi insentive yang menarik dan cenderung memotivasi, bahkan sering menunda pembayaran. Misal: insentive biasanya dibayar pada akhir tahun akan tetapi dengan berbagai alasan pembayaran sering macet dan bahkan sampai menimbulkan aksi demo karyawan.

5. Hilangnya sambung rasa: Terjadinya pengkotak-kotakan penugasan yang berdampak pada meningkatnya isolasi sosial dalam lingkungan kerja. Misal: adanya job desk yang terlalu kaku, gaya manajemen devide et empera yang suka memelihara konflik dan sebagainya.

6. Perlakuan yang tidak adil: Perlakuan yang tidak sama dan bukan berdasarkan kompetensi melainkan like or dislike. Misal: kebijakan yang arogan, tidak adanya sistem imbalan yang jelas dan baku, diskriminasi berdasarkan pada kesamaan suku, kesamaan alumni, kesamaan minat, nepotisme, dan sebagainya.

7. Terjadinya konflik nilai: Ketidak sesuaian antara prinsip pribadi dengan tuntutan pekerjaan. Misal: penugasan yang mengharuskan mereka menyogok, berbohong, ataupun taktik lain yang menghalalkan segala cara namun aktifitas tersebut bertentangan dengan nilai moral yang diyakininya.

Untuk menentukan kinerja terbaik (performance excellent) dalam kapasitas sumber daya manusia, tentu dipakai penilaian kinerja. Penilaian dapat didefinisikan sebagai peninjauan secara sistematis terhadap kinerja karyawan individu pada pekerjaan yang digunakan untuk mengevaluasi efektivitas kerjanya Muchinsky P.(1993). Lebih lanjut dikatakan bahwa tujuan dari program penilaian terbagi menjadi tiga kategori:

1. Administrative: Melibatkan tindakan personel, seperti kenaikan gaji, promosi, transfer, atau pemberhentian.

2. Pengembangan: Menggunakan infomation penilaian untuk mengidentifikasi kelemahan dalam kinerja; ini membantu memandu karyawan dalam menetapkan tujuan untuk perbaikan. 
3. Research: Informasi Penilaian kinerja sering digunakan sebagai kriteria untuk menilai keabsahan seleksi personil dan prosedur pelatihan.

Menilai kinerja terbaik sebagai kapasitas dari sumber daya manusia, menurut Hertz Harry S.(2012), mengemukakan bahwa kriteria penilaian kinerja terbaik, dapat dikategorikan sebagai berikut:

1. Kepemimpinan: kategori kepemimpinan diuji bagaimana pimpinan senior organisasi dalam pelaksanaan petunjuk keberlanjutan organisasi, juga pengujian system organisasi yang baik serta bagaimana organisasi melakukan legalisasi, etika dan dukungan tanggung jawab sosial sebagai kunci komunikasi. Hal ini meliputi visi nilai-nilai dan misis, komunikasi dan kinerja organisasi. Pengelolaan tanggungjawab masyarakat: Bagaimana melakukan pengelolaan dan mengisi tanggungjawab kepada masyarakat. Pengelolaan organisasi yang menyangkut kepada sistem pengelolaan dan evaluasi kinerja, legal dan perilaku etika yaitu regulasi dan etika perilaku, dukungan tanggungjawab masyarakat yang menyangkut pada hak sosial dan dukungan komunitas.

2. Strategi perencanaan: Strategi pengembangan dan strategi pelaksanaan. Pada strategi pengembangan; bagaimana mengembangkan strategi dalam proses dan strategi konsiderasi, strategi kunci objektif dan konsiderasi objektif. Sedangkan pada strategi implementasi yaitu bagaimana mengimplementasi strategi; pelaksanaan perencanaan dan pengembangan, pengukuran proyeksi kinerja.

3. Fokus pada Pelanggan: Suara pelanggan yaitu bagaimana mendapatkan informasi yang berguna dari pelanggan, dengan cara; mendengar pelanggan tetap dan pelanggan potensial, mengelola determinasi kepuasan pelanggan; pengelolaan kepuasan pelanggan, kompetisi kepuasan relative dan ketidakpuasan. Pengelolaan konsumen yaitu bagaimana mengelola pelanggan dalam memberi dukungan terhadap kebutuhan pengembangan komunikasi; penawaran produk dan dukungan pelanggan; pengembangan hubungan pelanggan terhadap pihak manajemen dan manajer penampung keberatan.

4. Pengukuran, Analisis dan Manajemen pengetahuan: Pengukuran kinerja, analisis perbandingan data, data pelanggan dan egalitas pengukuran; ringkasan analisis kinerja dan perbaikan kinerja organisasi yaitu pelaksanaan diskusi hal terbaik, kinerja masa depan, inovasi dan perbaikan berkelanjutan. Manajemen informasi, pengetahuan dan teknologi informasi yaitu bagaimana mengelola informasi, pengetahuan informasi, dan teknologi informasi.

5. Fokus tim kerja: Tim kerja lingkungan yaitu bagaimana membangun efektifitas dan dukungan timkerja lingkungan. Menyangkut pada kapabilitas dan kapasitas; pengesahan kerja, pertukaran manajemen timkerja dan iklim timkerja lingkungan dan tujuan serta manfaat. Pengelolaan timkerja; bagaimana mengelola timkerja untuk mencapai suksesi individu dan organisasi: ukuran kinerja timkerja, penilaian timkerja, pengembangan kepemimpinan timkerja. 
6. Fokus Operasi: Sistem kerja; bagaimana mendesign, memimpin, dan memperbaiki sistem kerja, baik sistem design, sistem manajemen kerja dan mengantisipasi hal darurat. Proses kerja; bagaimana mendesign, memimpin, memperbaiki kunci proses kerja, meliputi proses design kerja dan manajemen proses kerja.

7. Hasil Akhir: Produk dan Proses hasil akhir; kinerja produksi dan proses produktifitas hasil akhir; fokus produk pelanggan dan proses akhir, efektifitas proses operasional hasil akhir dan strategi implementasi hasil akhir. Fokus hasil akhir pelanggan; fokus kinerja hasil akhir pelanggan terdiri dari kepuasan konsumen dan pengelolaan pelanggan. Fokus hasil akhir timkerja; fokus kinerja hasil akhir timkerja terdiri dari kapabilitas dan kapasitas timkerja, sifat timkerja, pengelolaan timkerja dan pengembangan timkerja.

\section{Motivasi Kerja Berprestasi Sebagai Kapasitas SDM}

Motivasi kerja dapat dirumuskan sebagai kondisi ataupun tindakan yang mendorong seseorang untuk melakukan suatu pekerjaan atau kegiatan semaksimal mungkin karyawan untuk berbuat dan berproduksi dan berperan untuk mengintensifkan hasrat atau keinginan. Motivasi dapat didefinisikan sebagai keadaan dalam diri individu yang menyebabkan mereka berperilaku dengan cara untuk dapat menjamin tercapainya suatu tujuan Fendy Suhariadi (2013). McClelland (1953) memberikan pengertian motivasi berprestasi sebagai berikut: achievement motivation is desire to do well not so much for the sake of social recognition or prestige but to attain an inner feeling or personal accomplishment. Success in competition with some standard of excellence. Pada dasarnya bahwa manusia dalam kapasitasnya mempunyai keinginan untuk melakukan sesuatu hal yang berprestasi lebih dari kemampuan orang lain, hanya saja sering tidak mampu diwujudkan dikarenakan berbagai faktor yang berhubungan dengan manusia itu sendiri. Demikian halnya dengan para pelaku Insentive Travel dalam suatu Perusahaan swasta, yang terdiri dari Sumber daya manusia dalam suaru rangkaian struktur organisasi Perusahaan, mulai dari Manager, Supervisi sampai kepada Operator harus selalu berusaha untuk mengembangkan kapasitasnya untuk berprestasi. McClelland dalam Sukadji (2001), mengemukakan ciri-ciri individu dengan motif berprestasi yang tinggi, antara lain: 1 .Selalu berusaha dan tidak mudah menyerah dalam mencapai sesuatu kesuksesan maupun dalam berkompetisi, dengan menentukan sendiri standard bagi prestasinya. 2. Menampilkan hasil yang lebih baik pada tugas-tugas khusus. 3. Cenderung untuk mengambil resiko yang wajar dan dapat diperhitungkan. 4. Dalam melakukan tindakan, tidak semata-mata didorong oleh penghargaan saja. 5. Berharap memperoleh umpan balik dari perbuatannya. 6. Mencermati lingkungan dan selalu mencari peluang. 7. Bergaul untuk memperoleh pengalaman. 8. Menyukai tantangan untuk dapat mengaplikasikan kemampuan yang dimiliki. 9. Kecenderungan mencari cara yang unik dalam penyelesaian masalah. 10. Kreatif dalam bekerja 11.Selalu bekerja dengan waktu yang tepat. 


\section{Pengembangan Kapasitas SDM Dalam Program Incentive Travel}

Berbagai upaya pengembangan kapasitas Sumber daya manusia yang telah dilaksanakan oleh Pemerintah, Masyarakat maupun Perusahaan, namun belum mampu menghasilkan kinerja karyawan/aparatur sebagaimana yang diharapkan, apalagi dengan kapasitas sumber daya manusia dari Daerah di Indonesia yang sering sangat tidak memenuhi syarat dalam memenuhi tuntutan pasar kerja. Namun disisi lain sebenarnya posisi sumber daya lokal sangat strategis untuk dikembangkan kapasitasnya dalam pekerjaan pariwisata yang sangat femilier dengan basis adat, budaya dan kearifan lokal setempat yang menjadi ciri dari suatu pariwisata daerah tertentu. Beberapa faktor penghambat dalam pengembangan kompetensi Sumber daya manusia antara lain: disiplin yang kurang, motivasi kerja kurang, inovasi dan kreativitas kerja kurang, kelangkaan serta rendahnya pendidikan. Menurut Grindle (1997) yang menempatkan pengembangan kapasitas SDM sebagai prioritas dalam program capacity building, perlu dipertimbangkan oleh jajaran pemerintah daerah. Dalam kaitannya dengan aspek SDM, maka pengertian capacity building disini lebih diarahkan pada konsep Bank Dunia (1997) yaitu: "Capacity building refers to investment in people, institutions, and practises that will, together, enable countries in the region to achieve their development objectives".

Menurut Severt K \& Breiter D (2010), yang dikuatkan oleh David Kelly (2014), bahwa Program Insentive Travel merupakan suatu alat motivasi untuk meningkatkan produktivitas dan objektifitas bisnis melalui sumber daya yang berhasil mendapatkan penghargaan pada tingkat pencapaian kinerja spesifik yang dirancang manajemen perusahaan. Sumber daya manusia dihargai dengan suatu program perjalanan untuk rekoqnisi atas pencapaian kinerja. Selanjutnya elemen program incentive travel untuk mendorong menjadi sukses dalam pengembangan kapasitas manager, supervisi dan operator Insentive Travel, terdiri dari:

1. Penetapan kriteria seleksi penerima hadiah harus jelas terkait dengan tujuan bisnis.

2. Komunikasi program dan kemajuan peserta menuju tujuan harus jelas dan konsisten.

3. Rancangan program wisata, termasuk tujuan yang diinginkan, sesi interaktif dan waktu luang untuk penerima, harus menambah kegembiraan secara keseluruhan.

4. Eksekutif dan manajer kunci harus bertindak sebagai pemandu untuk memperkuat komitmen pada program reward dan rekoknisi.

5. Perusahaan harus menyimpan catatan rinci yang membuktikan produktivitas penghasilan dan kontribusi mereka terhadap kinerja keuangan perusahaan.

6. Selain itu, untuk memaksimalkan manfaat dari program perjalanan insentif, bahwa acara perjalanan insentif harus disertakan:

7. Rekoknisi penerima.

8. Kesempatan Networking untuk para top performer untuk membangun hubungan dengan top performer lainnya dan manajemen kunci. 
9. Kolaborasi antara top performer dan manajemen tentang praktik dan ideide terbaik.

10. Motivasi dari penerima untuk terus mencapai kinerja yang tinggi.

Pengembangan Pariwisata MICE di Indonesia sangat gencar dilakukan oleh Pemerintah sekarang ini dalam rangka usaha mendapatkan devisa Negara. Pengembangan yang dimaksud tergantung bagaimana cara untuk memajukan kapasitas yang dimiliki. Menurut Kesrul (2004:3), Mice sebagai suatu kegiatan kepariwisataan yang aktifitasnya merupakan perpaduan antara leisure dan business, biasanya melibatkan sekelompok orang secara bersama-sama, rangkaian kegiatannya dalam bentuk meetings, incentive travels, conventions, congresses, conference dan exhibition. Adapun bentuk Pariwisata MICE terdiri dari, sebagai berikut:

1. Meeting adalah istilah bahasa inggris yang berarti rapat, pertemuan atau persidangan. Kesrul (2004), Meeting adalah suatu kegiatan kepariwisataan yang aktifitasnya merupakan perpaduan antara leisure dan business, biasanya melibatkan orang secara bersama-sama.

2. Incentive. Undang-undang No.9 tahun 1990 yang dikutip oleh Pendit (1999:27), menjelaskan bahwa perjalanan insentive merupakan suatu kegiatan perjalanan yang diselenggarakan oleh suatu perusahaan untuk para karyawan dan mitra usaha sebagai imbalan penghargaan atas prestasi mereka dalam kaitan penyelenggaraan konvensi yang membahas perkembangan kegiatan perusahaan yang bersangkutan. Menurut Kesrul (2004:18), bahwa insentive merupakan hadiah atau penghargaan yang diberikan oleh suatu perusahaan kepada karyawan, klien, atau konsumen. Bentuknya bisa berupa uang, paket wisata atau barang.

3. Conference. Menurut Pendit (1999:29), Istilah conference diterjemahkan dengan konferensi dalam bahasa Indonesia yang mengandung pengertian sama. Dalam prakteknya, arti meeting sama saja dengan conference, maka secara teknis akronim mice sesungguhnya adalah istilah yang memudahkan orang mengingatnya bahwa kegiatan-kegiatan yang dimaksud sebagai perencanaan, pelaksanaan dan penyelenggaraan sebuah meeting, incentive, conference dan exhibition hakekatnya merupakan sarana yang sekaligus adalah produk paketpaket wisata yang siap dipasarkan.

4. Exhibition berarti pameran, oleh Pendit (1999:34) yang berbunyi Pameran merupakan suatu kegiatan untuk menyebar luaskan informasi dan promosi yang ada hubungannya dengan penyelenggaraan konvensi atau yang ada kaitannya dengan pariwisata.

\section{Kebijakan Pemerintah dalam Pengembangan Pariwisata MICE}

Paradigma kebijakan Pemerintah untuk mendatangkan devisa sekaligus mempromosikan produk-produk Indonesia dan potensi lainnya, adalah melalui kegiatan Meeting, Incentive, Convention dan Exhibition (MICE). Perlunya arah haluan kebijakan Pemerintah dalam peningkatan kapasitas Sumber daya manusia Pariwisata MICE yang berbasis profesionalisme dan kompetensi melalui pendampingan dan kerjasama dengan lembaga pendidikan dan pelatihan baik di 
dalam maupun di luar negeri. Melakukan kebijakan dalam pengembangan kapasitas sumber daya manusia dalam penguatan kearifan lokal dan mempertahankan budaya yang dapat mendukung dan meningkatkan daya saing destinasi pariwisata MICE, serta keberanian Pemerintah dalam berinvestasi dalam promosi dan pemasaran Pariwisata MICE Indonesia terhadap pasar pariwisata Internasional. Pengelolaan Sumber daya manusia Pariwisata MICE telah dituangkan dalam UU no 10 tahun 2004, dimana dalam bab 3 pasal 5 mengenai sumber daya manusia pariwisata dalam pembangunan kepariwisataan, berbunyi sebagai berikut:

a. sumber daya alam ciptaan Tuhan Yang Maha Esa berupa letak geografi, kepulauan, laut, flora dan fauna, sungai, danau, hutan bentang alam, iklim;

b. sumber daya hasil karya manusia berupa hasil-hasil rekayasa sumber daya alam, perkotaan, kebudayaan, nilai-nilai sosial, warisan sejarah, dan teknologi,

c. sumber daya manusia berupa kesiapan, kompetensi, komitmen dan peran serta masyarakat. UU No.10 Tahun (2004).

Upaya pengembangan kapasitas Sumber daya manusia dibidang Pariwisata Mice ini dapat dilakukan dengan berbagai cara penataan dalam pendayagunaannya, perencanaan yang baik dan komprehensif sesuai kebutuhan, serta pelaksanaannya dilakukan secara berkesinambungan yang dapat ditempuh melalui jalur pendidikan formal dan non formal, maupun pengembangan standar kompetensi yang dibutuhkan dalam pengembangan dan implementasi pariwisata Mice sejajar dengan kebijakan pemerintah pusat maupun di daerah, seperti:

1. Meningkatkan kemampuan dan pemahaman tentang pentingnya teknologi informasi dan komunikasi bidang pariwisata Mice, baik di kalangan pemerintah, swasta dan masyarakat.

2. Pengembangan pedoman dan perangkat penyelenggaraan pendidikan dan pelatihan pariwisata Mice bagi lembaga pemerintah agar hasil pendidikan dan pelatihan tersebut sesuai dengan kebutuhan pengembangan pariwisata berbasis lingkungan daerah.

3. Penyelenggaraan pendidikan dan pelatihan pariwisata Mice yang bertujuan untuk mentransfer pengetahuan/keterampilan yang dimiliki kepada masyarakat di lingkungan wisata.

4. Melakukan kerjasama dalam upaya peningkatan kapasitas penyelenggaraan pendidikan dan pelatihan dengan jarak jarak jauh (distance learning) dengan memanfaatkan teknologi informasi dan komunikasi secara optimal dari suatu daerah dimana pariwisata Mice dapat sukses dan berkembang.

5. Melakukan upaya penguatan mind set pariwisata Mice, sikap dan budaya kerja dalam keberhasilan pariwisata Mice.

6. Peningkatan motivasi melalui pemberian penghargaan kepada seluruh Sumber daya manusia pariwisata yang secara aktif memberikan gagasan pemikiran, inovasi maupun karya yang bermanfaat bagi pengembangan kapasitas sumber daya manusia pariwisata Mice. 
7. Pemanfaatan institusi pendidikan dan pelatihan pariwisata Mice di daerah yang dimiliki oleh Pemerintah, swasta dan masyarakat untuk mendukung upaya pemerataan kapasitas sumber daya manusia.

\section{KESIMPULAN DAN REKOMENDASI}

Berdasarkan hasil analisis bahwa peluang pertumbuhan pariwisata dapat dipeoleh dari kemajuan teknologi informasi dan komunikasi pariwisata dalam dan luar negeri dengan meningkatkan venue alamiah dan budaya pada setiap destinasi pariwisata Indonesia, yang menjadi potensi kekuatan pariwisata kita. Sementara yang menjadi tantangan dan kekurangan kita adalah daya saing sumber daya manusia pariwisata khususnya pada penyelenggara Pariwisata MICE serta lemahnya daya dukung kebijakan Pemerintah yang strategis dalam meningkatkan Potensi Pariwisata MICE. David Kelly (2012) menguatkan Severt K \& Breiter D (2010), merekomendasikan elemen Insentive Travel untuk dipahami sebagai pengembangan kapasitas penyelenggara Insentive Travel agar menjadi sukses, antara lain: 1). Kriteria seleksi penerima penghargaaan harus jelas mengarah pada tujuan bisnis; 2). Komunikasi program dan progress peserta tentang tujuan kedepan harus jelas dan konsisten; 3). Design program perjalanan meliputi destinasi yang dinginkan dan terjangkau, sesi enteraktif dan hiburan yang menarik; 4). Eksekutif dan manager kunci bertindak sebagai pemandu dalam penguatan komitmen perusahaan pada program penghargaan dan rekognisi; 5). Perusahaan membuat laporan rinci perihal produktivitas penerima dan kontribusinya pada kinerja keuangan perusahaan. Selain itu, untuk memaksimalkan manfaat dari program perjalanan insentif harus disertakan 6). Rekognisi penerima; 7). Kesempatan networking bagi top performer untuk membangun hubungan dengan top performer lainnya dan manajemen kunci; 8). Kolaborasi diantara top performer dan manajemen tentang ide dan praktek kerja terbaik, dan 9). Motivasi penerima untuk melanjutkan pencapaian kinerja tinggi.

Sementara dalam pengembangan kapasitas Sumber daya manusia, terutama bagi penyelenggara Insentive Travel dan arah kebijakan Pemerintah, perlu untuk melakukan evaluasi dibidang, sebagai berikut:

1. Pengembangan Kapasitas Sumber daya manusia baik perorangan maupun swasta yang harus ditingkatkan agar mampu mengetahui kebutuhan dan bagaimana memberikan pelayanan yang baik terhadap sumber daya manusia berprestasi pada sektor perusahaan swasta khususnya pelayanan pariwisata MICE sehingga menimbulkan suatu daya tarik dan kesan tersendiri serta memuaskan. Hal lain adanya dukungan seluruh masyarakat dalam memberikan akses terhadap pelayanan wisata yang baik serta profesionalitas para penyelenggara Pariwisata Mice dalam merencanakan dan menyusun proposal event, memenangkan tender, menyusun acara rapat/seminar/pameran/konferensi, merancang kegiatan sponsorship, menerapkan dan monitoring manajemen event, mengkordinasi kegiatan registrasi yang baik, pelayanan saat event, mengkordinir acara ramah tamah dan kegiatan budaya sebagai tambahan acara event. 
2. Kebijakan Pemerintah Pariwisata MICE, harus dievaluasi secara terus menerus terutama daerah destinasi pariwisata yang membutuhkan konnektivitas akses transportasi udara, laut dan darat. Bandara Internasional dengan jadwal penerbangan yang selalu siap, pelayanan kepabeanan dan imigrasi yang baik.

3. Venue Alam yang baik dan menarik yang selalu terjaga rapi oleh penataan berkesinambungan oleh Pemerintah dan Keramahan serta sopan santun dalam budaya Masyarakat yang selalu baik. Juga terhadap kebutuhan Venue wisata MICE yang memadai sesuai standart Internasional, tempat yang strategis, harga dan kualitas yang cukup bersaing, suasana dan pelayanan yang nyaman dan dapat menimbulkan daya tarik wisata domestik dan mancanegara.

\section{DAFTAR PUSTAKA}

Bernardin H. John. 2003. Human Resources Management: An Experiential Approach, 3rd edition, McGraw-Hill/Irwin, New York.

BPS Sumut, 2014, Dep. Pariwisata Bagian Marketing MICE, Medan.

Christina R.L, 2009, Materi Workshop MICE, Polmed, Medan.

Gomes, F. Cardoso.(2000), Manajemen Sumber Daya Manusia, Penerbit Andi Offset, Jakarta.

Grindle, Merilee S., 1997, Capacity Building, an Approach to People-Centered Development, Oxford: Oxfam Publications

Hertz Harry S, 2012, Criteria for Performance Excellence, Baldrige NIST, Gaichersburg, MD 20899-1020.

Incentive Research Foundation, 2014, Incentive Travel, Motivation, Sales Incentive, IRF Resource Center, New York.

Jeffrey A.Scott, 2014, Jurnal The Motivasional Power of Incentive Travel: The Participant's Perspective, Monmouth University. West Long Branch, NJ 07764.

Keiger Alin, 2011, Volunteerism and its Role in the Incentive Travel Market: Perception and Use by Intermediaries and Companies Residing in Germany, Architecture and Environment, Germany.

Kelly David 2014, What is Incentive Travel, Incentive Research Foundation, New York.

Kemenparekraf, 2004, UU No.10 Pengelolaan Pariwisata MICE, Jakarta

Kemenparekraf, 2014, FGD Penyusunan Strategi Pengembangan Destinasi MICE Indonesia, Medan, 5 Juni 2014.

Kementerian Perdagangan Republik Indonesia, 2011, Potensi Industri MICE Indonesia, Warta Ekspor, DJPEN/MJL/002/07/2011, Edisi Juli, Jakarta.

Kesrul M, 2004, Meeting, Incentive Trip, Conference, Exhibition, Graha Ilmu, Yokyakarta.

Landmark Study 2008, The Market for Incentive Travel, Motivational Meetings and Special Events, Incentive Research Foundation.

Mahendratto Isywara, (2007), Kinerja karyawan menurun. http://servoclinic.com.

McCellannd, David C, 1953, The Achievement Motive, New York: Appleton Century Croffs. 
McKinsey, 2013, Advancing the Science of Motivation and Incentives Through Research, IRF, New York.

Muchinsky Paul M, 1993, Psychology Applied to Work, An Introduction to Industrial and Organizational Psychology, Iowa State University, Books/Cole Publishing Company Pacific Grove, California.

Myers Anthony, 2013, Top Performing Companies Have Excecutives Who Collaborate the Most with IT, CMSwire.com.

Nembhard Ingrid M. at all, 2014, Learn-how to Improve Collaboration and Performance, Yale University, School Medicine \& School of Management, New Haven, CT 06520.

Nicholls John G., 1984, Achievement Motivation: Conceptions of Ability, Subjective Experience, Task Choice, and Perormance, Psychological Review , Vol. 91, No. 3. 328-346, American Psychological Association, Inc., Purdue University.

Pendit S Nyoman, 1999, Wisata Konvensi, Penerbit PT. Gramedia Pustaka Utama, Jakarta.

Richard Clark E., 2013, Fostering the Work Motivation of Individuals and Teams, University of Southern California, USA.

Severt S. Kimberly \& Breiter Deborah (2010), The Anatomy of an Incentive Travel Program, University of Central Florida.

Solahuddin, 2014, Operasional kuala namu harus tepat waktu, Waspada Online Pusat berita \& Informasi Medan Sumut Aceh, http://waspada.co.id/index.php, Medan.

Suhariadi Fendy, 2013, Manajemen Sumber Daya Manusia Dalam Pendekatan TeoretisPraktis, Airlangga University Press (AUP), Surabaya.

Taylor \& Francis 2014, Journal Insentive Travel \& Tourism Marketing, Sales Marketing Network Publications.

Wayne \& Casio, 2009, Journal The Motivational Power of Incentive Travel: The Participant's Perspective, Monmouth University, Leon Hess Business School, 400 Cedar Ave. West Long Branch, NJ.

Wicaksono Dani Agung, (2013), Pengembangan SDM, Jurnal Vol.10, Untag Banyuwangi.

World Bank, 1997, Partnership for Capacity Building in Africa: A Progress Report, New York 